\title{
Cancer-Related Intracellular Signalling Pathways Activated by DOXorubicin/Cyclodextrin-Graphene-Based Nanomaterials
}

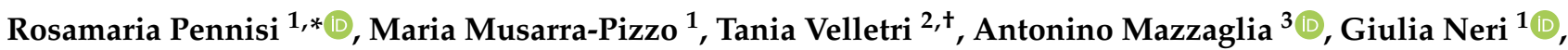 \\ Angela Scala ${ }^{1}{ }^{\mathbb{D}}$, Anna Piperno ${ }^{1} \mathbb{D}$ and Maria Teresa Sciortino ${ }^{1, *}$
}

1 Department of Chemical, Biological, Pharmaceutical and Environmental Sciences, University of Messina, 98166 Messina, Italy; mmusarrapizzo@unime.it (M.M.-P.); giulia.neri@unime.it (G.N.); ascala@unime.it (A.S.); apiperno@unime.it (A.P.)

2 IFOM-Cogentech Società Benefit srl; via Adamello 16, 20139 Milan, Italy; tania.velletri@cogentech.it

3 Istituto per lo Studio dei Materiali Nanostrutturati, Consiglio Nazionale delle Ricerche (ISMN-CNR), V.le F. Stagno d'Alcontres 31, 98166 Messina, Italy; antonino.mazzaglia@cnr.it

* Correspondence: rpennisi@unime.it (R.P.); maria.sciortino@unime.it (M.T.S.)

† Local Unit: Scientific and Technological Park of Sicily, 95121 Catania, Italy.

check for updates

Citation: Pennisi, R.; Musarra-Pizzo, M.; Velletri, T.; Mazzaglia, A.; Neri, G.; Scala, A.; Piperno, A.; Sciortino, M.T. Cancer-Related Intracellular Signalling Pathways Activated by DOXorubicin/CyclodextrinGraphene-Based Nanomaterials. Biomolecules 2022, 12, 63. https:// doi.org/10.3390/biom12010063

Academic Editors:

Miguel Ángel Esteso and Ana Cristina Faria Ribeiro

Received: 25 November 2021 Accepted: 30 December 2021 Published: 1 January 2022

Publisher's Note: MDPI stays neutral with regard to jurisdictional claims in published maps and institutional affiliations.

Copyright: (C) 2022 by the authors. Licensee MDPI, Basel, Switzerland. This article is an open access article distributed under the terms and conditions of the Creative Commons Attribution (CC BY) license (https:// creativecommons.org/licenses/by/ $4.0 /)$.

\begin{abstract}
In the last decade, nanotechnological progress has generated new opportunities to improve the safety and efficacy of conventional anticancer therapies. Compared with other carriers, graphene nanoplatforms possess numerous tunable functionalities for the loading of multiple bioactive compounds, although their biocompatibility is still a debated concern. Recently, we have investigated the modulation of genes involved in cancer-associated canonical pathways induced by graphene engineered with cyclodextrins (GCD). Here, we investigated the GCD impact on cells safety, the HEp-2 responsiveness to Doxorubicin (DOX) and the cancer-related intracellular signalling pathways modulated by over time exposure to DOX loaded on GCD (GCD@DOX). Our studies evidenced that both DOX and GCD@DOX induced p53 and p21 signalling resulting in $\mathrm{G}_{0} / \mathrm{G}_{1}$ cell cycle arrest. A genotoxic behaviour of DOX was reported via detection of CDK (T14/Y15) activation and reduction of Wee-1 expression. Similarly, we found a cleavage of PARP by DOX within $72 \mathrm{~h}$ of exposure. Conversely, GCD@DOX induced a late cleavage of PARP, which could be indicative of less toxic effect due to controlled release of the drug from the GCD nanocarrier. Finally, the induction of the autophagy process supports the potential recycling of DOX with the consequent limitation of its toxic effects. Together, these findings demonstrate that GCD@DOX is a biocompatible drug delivery system able to evade chemoresistance and doxorubicin toxicity.
\end{abstract}

Keywords: graphene-based platform; cancer therapy; intracellular signalling pathway; doxorubicin

\section{Introduction}

Over the past three decades, the application of nanotechnology in medicine has had a significant impact on cancer disease treatment. Several nanotherapeutics have been clinically approved to support conventional anticancer therapies, while many others are under clinical investigation [1-3]. These nanoparticles are characterised by sizes ranging from a few to a few hundreds of nanometres $(1-500 \mathrm{~nm})$ and superior surface properties that are able to improve the delivery and release of therapeutic agents at the site of action [4]. However, to date, the most important challenge in nanomedicine remains reducing toxicity profile and enhancing therapeutic efficacy. Carbon-based nanomaterials, including nanodiamonds, fullerenes, carbon nanotubes, graphene, and carbon nanofibers, have been proposed as useful biological platforms due to their versatility, physical properties, and unique intracellular trafficking properties [5-10]. Surface functionalisation with polymers such as polyethylenimine (PEI, branched/linear), cationic dendrimers, glycopolymers, and poly amidoamine increases their solubility and intracellular uptake and stabilises their half-life in the cellular environment [11-14]. The engineering of graphene surfaces 
with macrocycles such as $\beta$-cyclodextrins (CD) allows the formation of stable inclusion complexes with hydrophobic small molecules by means of host-guest interactions with the hydrophobic CD cavity $[15,16]$. Recently, we reported a graphene nanoplatform covalently modified with functional cationic cyclodextrins (GCD) [17] as a carrier for the purposes of gene and drug delivery. We analysed its endocytosis internalisation mechanism, its perinuclear localisation, and its ability to deliver miRNAs. Specifically, we studied the effects of the GCD/miRNA15a complex on the regulation of the oncogene protein BCL2. The GCD platform was proved to be a promising therapeutic miRNA delivery system that was able to overcome the problems typically encountered, such as low stability, nuclease susceptibility and weak cellular uptake. Next, we investigated the intracellular fate of DOX loaded on GCD (GCD@DOX), including the nuclear distribution responsible for the gene expression modulation (Scheme 1) [18]. The GCD nanoplatform contains several molecular recognition sites (i.e., cationic external CD rims to provide electrostatic interactions; $\pi$ systems to give $\pi-\pi$ interactions and/or hydrophobic effects; CD hydrophobic cavities to provide host/guest inclusion complexes). According to literature data, DOX can interact with GCD by: (i) $\pi-\pi$ stacking between the G conjugated structure and the quinone portion of DOX, as well as the hydrophobic effect between them; (ii) inclusion into the CD cavities; (iii) hydrogen bonding among $\mathrm{OH}$ and $\mathrm{COOH}$ groups of $\mathrm{G}$ and $\mathrm{OH}$ and $\mathrm{NH} 2$ groups of DOX $[19,20]$. Moreover, high formation constants were reported for inclusion complexes between functionalized $\beta C D$ s and DOX in mixed water: DMSO solutions $\left(2.3 \times 10^{4}\right.$ and $3.2 \times 10^{5} \mathrm{M}^{-1}$ ) [21]. A stronger interaction is expected in GCD with respect to the literature due to the GCD restored $\mathrm{sp}^{2}$ network and additional cationic sites on external CD rims. However, in our studies, GCD@DOX was prepared at a low actual loading (2.5\%) [18] to avoid the overloading of DOX on the $\mathrm{sp}^{2}$ network [22], and the aspects related to the binding constant between DOX and GCD were not investigated. Caveolae-mediated endocytosis was detected as the main pathway of GCD cellular internalisation. FLIM and Raman mapping analyses indicated the presence of GCD only in the cytoplasm, whereas fluorescence microscopy showed the DOX release in the nuclear and perinuclear region. Here, we expand the knowledge of graphene-cell interaction, focusing on the modulation of intracellular cell-death pathways. Additionally, we performed an in vitro time-dependent study to measure the initial responsiveness of tumour cells to chemotherapeutic drugs, and contextually evaluated the GCD@DOX-mediated changes in p53-related signalling. Although the extensive bibliography provided important information about the interactions between graphene-related nanomaterials and the induction of programmed cell death, reporting the impact of graphene on intracellular components, the production and secretion of proinflammatory cytokines, and the activation of a cascade of events [23-30], it should be considered inclusive with respect to differently functionalised graphene. In fact, the nanoplatform GCD, originated by engineering of G with $C D$, is endowed with unique properties originating from the synergic actions of single components that are not the result of the simple combination of the starting properties of native materials. 

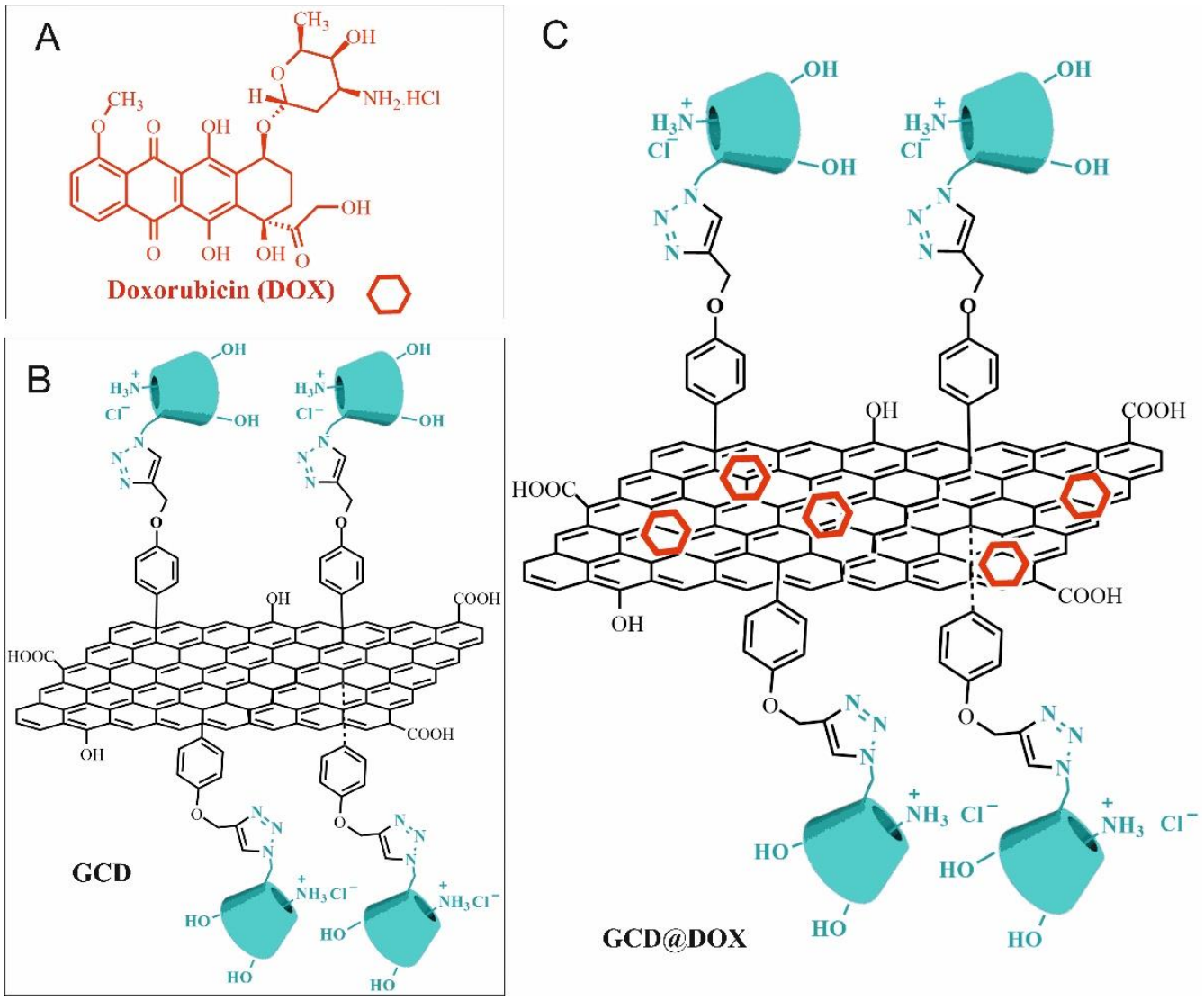

Scheme 1. (A) Doxorubicin (DOX); (B) schematic sketch of graphene functionalised with cationic cyclodextrins (GCD platform); (C) schematic sketch of DOX loaded on GCD (GCD@DOX). (Reprinted from reference [18]).

\section{Materials and Methods}

\subsection{Synthesis of Drug-Loaded GCD}

GCD@DOX complex was prepared using GCD and Doxorubicin (DOX) according to procedure previously reported. DOX content in GCD@DOX was 2.5\% [18]. Thus, $25 \mu \mathrm{g} / \mathrm{mL}$ of GCD@DOX contains $0.625 \mu \mathrm{g} / \mathrm{mL}$ of DOX.

\subsection{Cell Cultures}

Cell lines were originally obtained from the American Type Culture Collection (ATCC). HEp-2 cells were grown in RPMI 1640 medium (Lonza, Belgium), supplemented with $10 \% \mathrm{FBS}, 100 \mathrm{U} / \mathrm{mL}$ penicillin and $100 \mu \mathrm{g} / \mathrm{mL}$ streptomycin mixture, and were cultured at $37^{\circ} \mathrm{C}$ in a $5 \% \mathrm{CO}_{2}$ incubator.

\subsection{Antibodies}

Antibodies to p-Cdk (Thr14/Tyr15)-R (sc-28435-R) and to Wee-1 (B11; sc-5885) were purchased from Santa Cruz Biotechnology (Dallas, Texas, USA). Antibodies to phospho-p53 (Ser15; \#9284), p21 Waf1/Cip1 (12D1; \#2947), LC3B (D11;\#3868), and SQSTM 1-p62 (D5L7G; \#88588) were provided by Cell Signaling Technology ${ }^{\circledR}$ (Danvers, MA, USA). Polyclonal antibodies against the housekeeping gene GAPDH and Histone $\mathrm{H} 3$ were purchased from Abcam (Cambridge, UK) and Cell Signaling Technology ${ }^{\circledR}$, respectively. Secondary antibodies anti-rabbit and anti-mouse IgG conjugated to peroxidase were also from Merck Millipore (Darmstadt, Germany). 


\subsection{Protein Extractions and Immunoblot Analysis}

To obtain total protein extraction, cells were lysed in $62.5 \mathrm{mM}$ Tris-HCl pH 6.8; DTT $1 \mathrm{M} ; 10 \%$ glycerol; 2\% SDS; $0.01 \%$ Bromophenol Blue and held at $100{ }^{\circ} \mathrm{C}$ for $5 \mathrm{~min}$. Nuclear and cytoplasmic fractions were isolated as reported elsewhere [31] and analysed for protein determination using a Qubit ${ }^{\mathrm{TM}}$ Protein Assay Kit (Invitrogen ${ }^{\mathrm{TM}}$, Waltham, MA, USA). An equal amount of protein extracts was subjected to Sodium dodecyl sulfate-polyacrylamide gel electrophoresis (SDS-PAGE) and transferred to nitrocellulose membranes (Bio-Rad Life Science Research, Hercules, CA, USA). After incubation in blocking buffer, membranes were probed overnight at $4{ }^{\circ} \mathrm{C}$ with the specific primary antibody and then probed for $1 \mathrm{~h}$ at RT with secondary antibodies, followed by chemiluminescent detection, according to the manufacturer's instructions. Protein bands were visualised by using Immobilon Classico Western HRP substrate (Merk, Millipore, Burlington, MA, USA) and captured using a ChemiDoc Touch Imaging System (Bio-Rad, Hercules, CA, USA), where indicated. Quantitative densitometry analysis of immunoblot band intensities was performed using ImageJ software and graphically represented using GraphPad Prism 6 software (GraphPad Software, San Diego, CA, USA). Statistical analysis was performed by ANOVA followed by Bonferroni's Multiple Comparison Test.

\subsection{Cell Viability Assay}

The cell viability of HEp-2 cells treated with DOX, GCD and GCD@DOX was determined on the basis of ATP levels using ViaLightTM plus cell proliferation and cytotoxicity bioassay kit according to the manufacturer's instructions (Lonza Group Ltd., Basel, Switzerland). Cells were grown in 96-well plates and treated with different concentrations of indicated DOX $(1.25 \mu \mathrm{g} / \mathrm{mL}), \mathrm{GCD}(25 \mu \mathrm{g} / \mathrm{mL})$ and GCD@DOX $(25 \mu \mathrm{g} / \mathrm{mL})$. The contents of DOX in $25 \mu \mathrm{g} / \mathrm{mL}$ of GCD@DOX was $0.625 \mu \mathrm{g} / \mathrm{mL}$. After the indicated incubation time, the cells were harvested and the emitted light intensity related to ATP degradation was quantified with the GloMax Multi Microplate Luminometer (Promega Corporation, 2800 Woods Hollow Road Madison, WI, USA). The luminescence value was converted to the cell proliferation index and reported as percentage of cell viability (\%) according to the following equation:

$$
\text { Cell viability } \%=[(\mathrm{A}-\mathrm{B}) /(\mathrm{C}-\mathrm{B})] \%
$$

where A denotes the average of treated sample, B represents background luminescence, and $C$ represents the average of untreated samples.

\subsection{Acridine Orange Assay}

The morphological analysis of apoptotic cells was performed following staining with the fluorescent DNA-binding dye acridine orange (AO). Thus, HEp-2 cells were untreated and treated with $1.25 \mu \mathrm{g} / \mathrm{mL}$ of DOX and $25 \mu \mathrm{g} / \mathrm{mL}$ of GCD@DOX for $24 \mathrm{~h}, 48 \mathrm{~h}$ and $72 \mathrm{~h}$, collected on poly l-lysine-coated slides and stained with $\mathrm{AO}$ to determine the amount of apoptotic cells through fluorescence microscopy [32].

\subsection{Evaluation of Autophagy by Tandem mRFP-GFP-LC3 and by LC3-I, LC3-II/SQSTM-p62 Autophagy-Related Protein Detection}

Hep-2 cells were grown in multiwell culture slides and transiently transfected for $48 \mathrm{~h}$ with mRFP-GFPLC3 plasmid [33]. Twenty-four hours post-transfection, the cells were untreated and treated with $1.25 \mu \mathrm{g} / \mathrm{mL}$ and $25 \mu \mathrm{g} / \mathrm{mL}$ of DOX and GCD@DOX, respectively. Then, the samples were collected and washed twice with warm PBS, fixed with paraformaldehyde (PFA) $4 \%$ for $30 \mathrm{~min}$ at room temperature, and permeabilised with Triton $0.1 \%$ for $1 \mathrm{~h}$, covered with a drop of mounting solution (ProLong Diamond Antifade Mountant with DAPI-Invitrogen p36971) for $30 \mathrm{~min}$ in a dark room. The images were captured and processed using confocal laser scanning microscopy TCS SP8, Leica, (TCS SP8, Leica Microsystems Srl, Milan, Italy) (magnification, 63×). For the expression analysis of LC3-I, LC3-II and SQSTM-p62 proteins, HEp-2 cells were untreated or treated with GCD 
(25 $\mu \mathrm{g} / \mathrm{mL})$, GCD@DOX $(25 \mu \mathrm{g} / \mathrm{mL})$ and DOX $(1.25 \mu \mathrm{g} / \mathrm{mL})$ for $24 \mathrm{~h}, 48 \mathrm{~h}$ and $72 \mathrm{~h}$. The cells were then collected and processed for protein extraction and immunoblot analysis.

\section{Results}

\subsection{In Vitro Evaluation of DOX, GCD and GCD@DOX Biocompatibility}

Our recent findings regarding GCD indicated its ability to deliver DNA plasmid and miRNAs [17]. Moreover, we established that the fluorescence-labelled platform (GCD@AdaRhod) at a concentration of $25 \mu \mathrm{g} / \mathrm{mL}$ does not induce a cytotoxic effect and efficiently crosses cell membranes delivering genetic material. Herein, GCD was loaded with DOX to verify the drug-release efficiency by analysing specific intracellular signals. The sensibility and degree of resistance to DOX on HEp-2 cells was tested by monitoring the cytotoxicity at different treatment times (Figure 1). HEp-2 cells were pre-incubated overnight in 96-well plates with a final volume of $100 \mu \mathrm{L} /$ well at $37^{\circ} \mathrm{C}$ and $5 \% \mathrm{CO}_{2}$ and treated for $24 \mathrm{~h}, 48 \mathrm{~h}$ and $72 \mathrm{~h}$ with $1.25 \mu \mathrm{g} / \mathrm{mL}$ of DOX and $25 \mu \mathrm{g} / \mathrm{mL}$ of GCD@DOX and GCD. The results showed a low degree of toxicity after GCD and GCD@DOX treatment at $24 \mathrm{~h}(24 \%$ and $26 \%$, respectively) $(p<0.001)$, with a late recovery of vitality at $48 \mathrm{~h}$ and $72 \mathrm{~h}$. Conversely, DOX treatment was moderately toxic $(29 \%)$ at $48 \mathrm{~h}$ after exposure $(p<0.001)$.

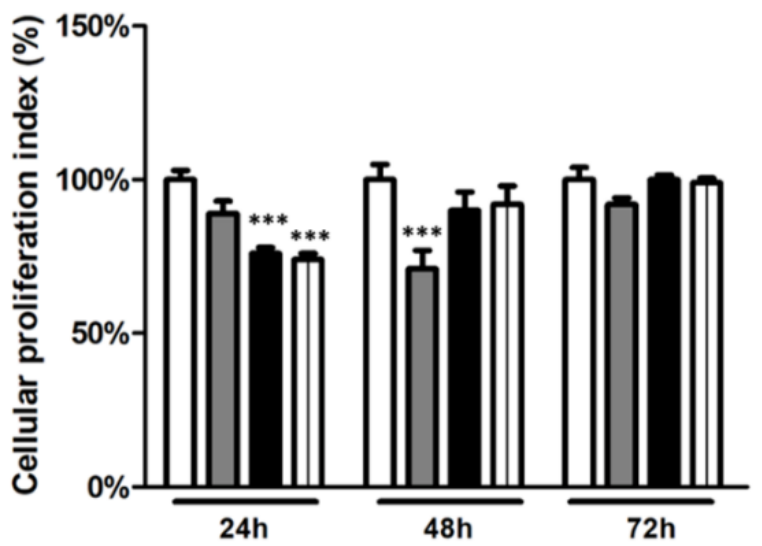

Figure 1. Time course study of biocompatibility of DOX $(1.25 \mu \mathrm{g} / \mathrm{mL}), \mathrm{GCD}(25 \mu \mathrm{g} / \mathrm{mL})$ and GCD@DOX $(25 \mu \mathrm{g} / \mathrm{mL})$ in HEp-2 cells. The cells were untreated or treated with DOX, GCD or GCD@DOX for $24 \mathrm{~h}, 48 \mathrm{~h}$ and $72 \mathrm{~h}$. The data show the \% of live cells compared to the untreated ones. The cellular proliferation index (\%) was determined on the basis of ATP level as described in Materials and Methods. GraphPad Prism 6 software was used for data analysis and graphical representation. The assay was performed as means of triplicates \pm SD. Statistical significance was tested by one-way ANOVA analysis assay in triplicate. $\left.{ }^{* * *} p<0.001\right)$.

\subsection{Investigation of p53 and Wee-1 Signalling Mediated by DOX, GCD and GCD@DOX Treatment}

The signal transduction pathways in response to damaged DNA lead to programmed cell death, repair mechanisms, or cell cycle arrest [34-36]. Ordinarily, checkpoint signalling ensures that DNA replication is arrested in damaged cells through proteins stalling the cell cycle or activating apoptotic mechanisms. The tumour-suppressor protein p53 is induced by DNA damage signals and counteracts the genomic instability of cancer cells through a wide range of biological processes [37,38]. Thus, the increased p53 expression promotes the accumulation of p21 (also known as p21 WAF1/Cip1), which is responsible for growth arrest through inhibition of the cyclin/cyclin-dependent kinase (CDK) complex, required for G1/S transition [39,40]. Therefore, HEp-2 cells were untreated and treated with $1.25 \mu \mathrm{g} / \mathrm{mL}$ of DOX and $25 \mu \mathrm{g} / \mathrm{mL}$ of GCD@DOX and GCD and collected after $24 \mathrm{~h}$, $48 \mathrm{~h}$, and $72 \mathrm{~h}$ of treatment. The accumulation of phospho-p53 and p21 was detected by Western blot analysis. As shown in Figure 2A and graphically reported in Figure 2B, an accumulation of phospho-p53 was detected in free DOX- and GCD@DOX-treated cells at $48 \mathrm{~h}$ and $72 \mathrm{~h}$ (Figure 2A, lanes 6, 7, 10 and 11). The expression of p21 peaked at $24 \mathrm{~h}$ and $48 \mathrm{~h}$ following free DOX treatment (Figure 2A lanes 2 and 6) and decreased over time. 
Conversely, p21 levels slowly increased at $72 \mathrm{~h}$ following GCD@DOX treatment (Figure 2A lanes 11 and Figure 2B). No significant changes in phospho-p53 or p21 expression levels were detected following treatment with GCD compared to untreated cells. Thus, the GCD alone did not impact the $\mathrm{p} 53 / \mathrm{p} 21$ signalling.

A

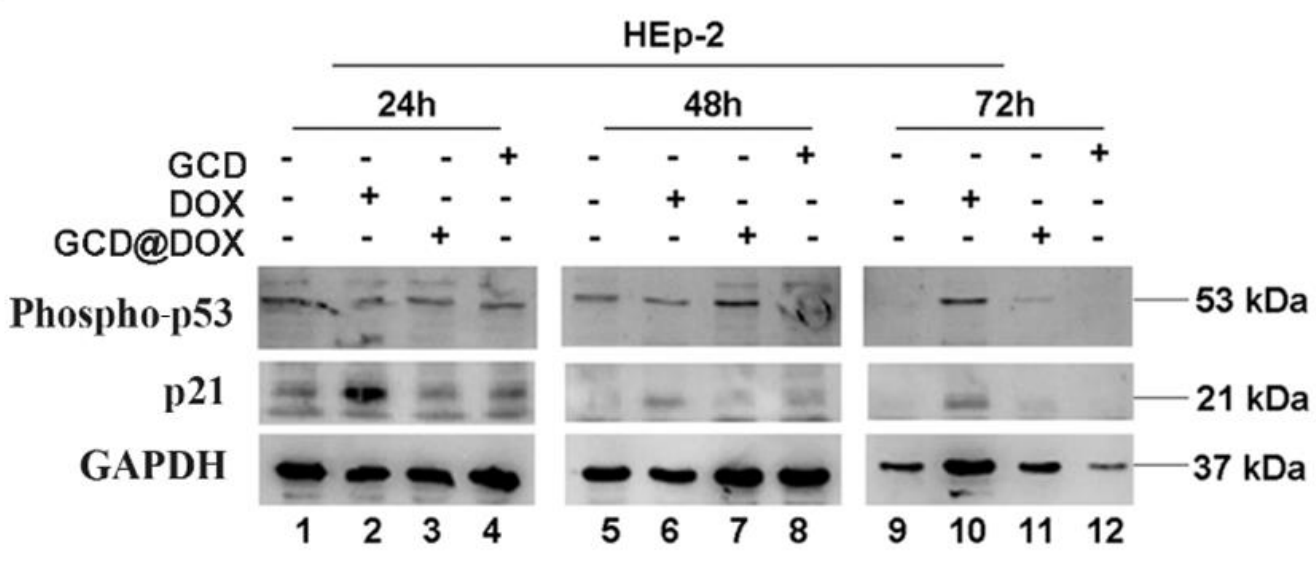

B
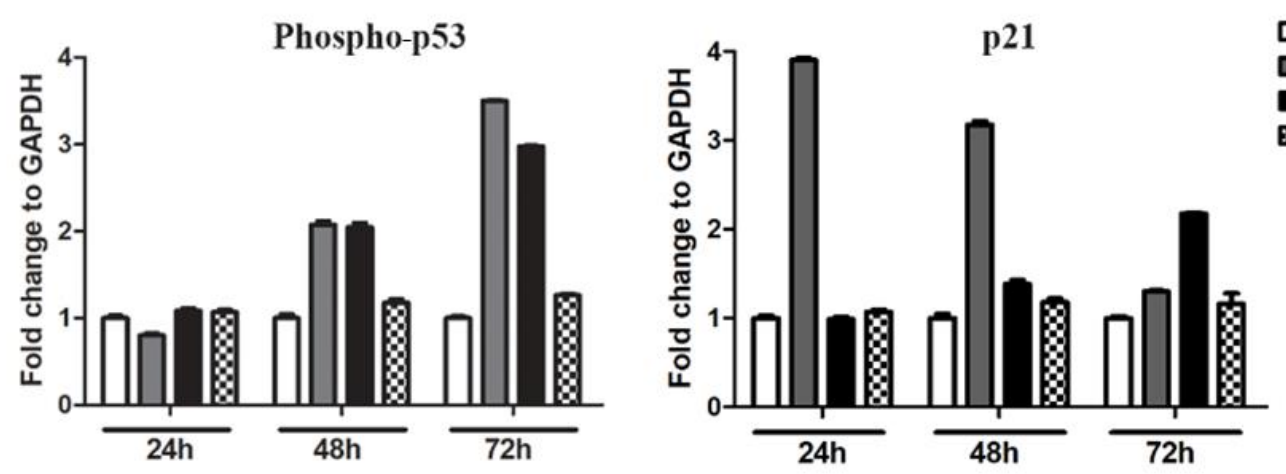

Figure 2. Phospho-p53 and p21 protein expression in GCD@DOX-, GCD- and DOX-treated cells. HEp-2 cells were treated or untreated with $25 \mu \mathrm{g} / \mathrm{mL}$ of GCD@DOX for the indicated time $(24 \mathrm{~h}, 48 \mathrm{~h}$ and $72 \mathrm{~h}$ ). DOX and GCD were used as controls. (A) An equal amount of proteins was separated by polyacrylamide gel electrophoresis and probed with a specific antibody to phospho-p53 and p21. GAPDH was used as housekeeping gene. (B) The quantitative densitometric analysis for phosphop53 and p21 band intensities was determined using ImageJ software and expressed as fold change over the appropriate housekeeping gene.

While p53 and p21 are considered mediators of $\mathrm{G}_{0} / \mathrm{G}_{1}$ cell cycle arrest, Wee- 1 blocks $\mathrm{G}_{2} / \mathrm{M}$ transition [41]. Wee-1 is an inhibitory kinase that catalyses the phosphorylation of tyrosine 15 (Y15) on CDK, rendering it inactive and blocking CDK-cyclin interaction and cell cycle progression $[41,42]$. Then, the spatio-temporal regulation of Wee- 1 was detected on HEp-2 cell lines, untreated and treated with DOX $(1.25 \mu \mathrm{g} / \mathrm{mL})$, GCD@DOX $25 \mu \mathrm{g} / \mathrm{mL}$ and GCD $(25 \mu \mathrm{g} / \mathrm{mL})$, and collected at $24 \mathrm{~h}, 48 \mathrm{~h}$, and $72 \mathrm{~h}$ of treatment. The results are shown in Figure 3A and graphically reported in Figure 3B. We found that in both the untreated cells and cells treated with GCD and GCD@DOX, Wee-1 expression grew over time in the cytoplasm and maintained unchanged levels in the nucleus. Conversely, Wee-1 accumulation was significantly inhibited by DOX treatment in both cellular compartments $\left.{ }^{*} p<0.1{ }^{* * *} p<0.001\right)$ compared with the untreated cells. At the same time, DOX influences pCDK2 T14/Y15; indeed, increased levels were detected in the cytoplasm and nucleus compared to untreated cells $\left({ }^{* *} p<0.001\right)$. 
HEp-2
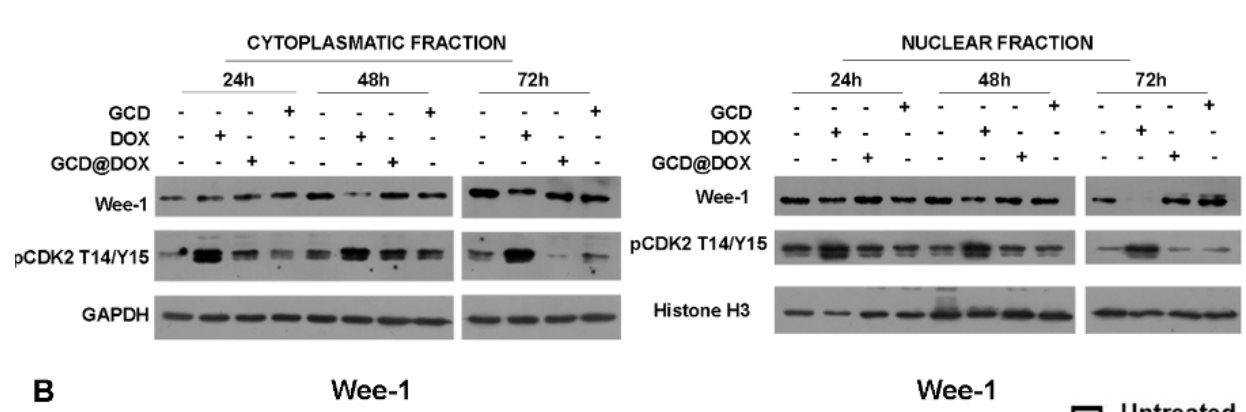

B
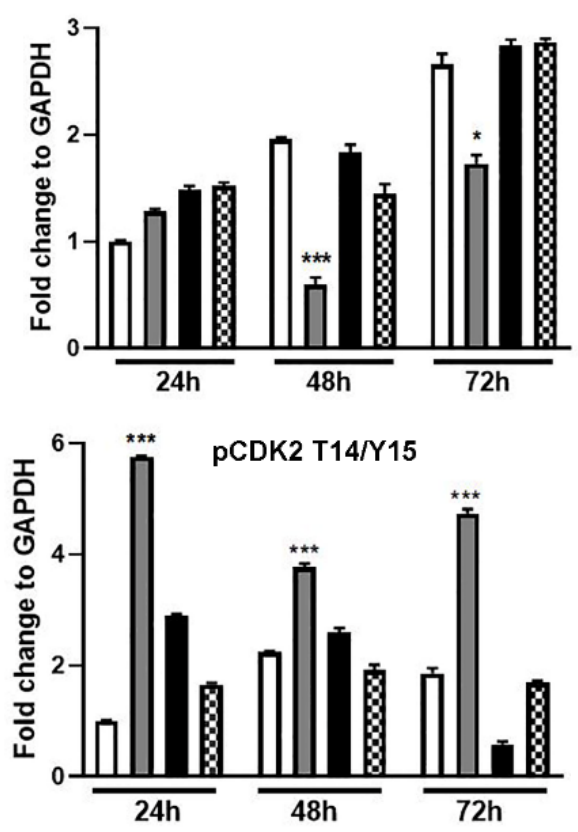

Wee-1
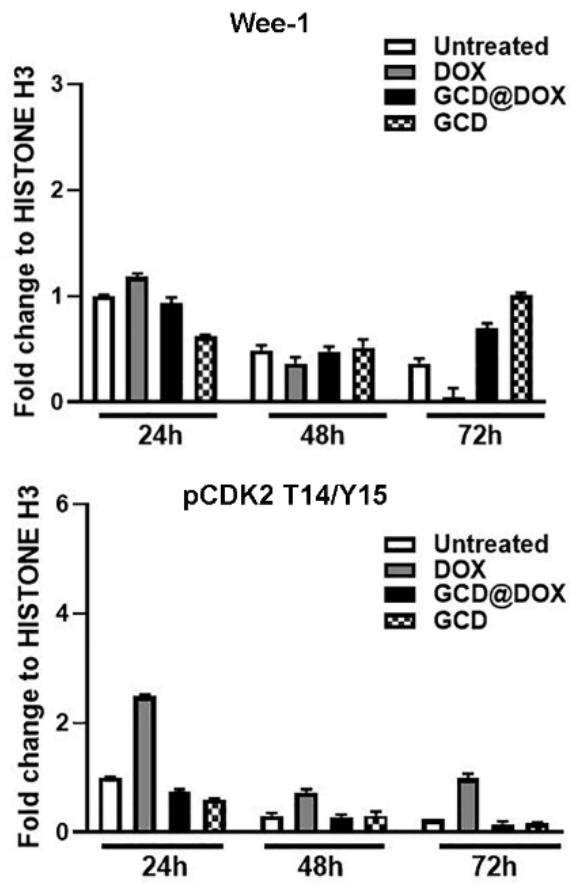

Figure 3. Wee-1 and phospho-CDK2 (pCDK2 T14/Y15) protein expression in GCD@DOX-, GCDand DOX-treated cells. HEp-2 cells were untreated or untreated with $25 \mu \mathrm{g} / \mathrm{mL}$ of GCD@DOX for $24 \mathrm{~h}, 48 \mathrm{~h}$ and $72 \mathrm{~h}$. DOX $(1.25 \mu \mathrm{g} / \mathrm{mL})$ and GCD $(25 \mu \mathrm{g} / \mathrm{mL})$ were used as controls. (A) An equal amount of cytoplasmic and nuclear proteins was separated by polyacrylamide gel electrophoresis and probed with Wee-1 and phospho-CDK2 (pCDK2 T14/Y15) antibodies. GAPDH and Histone $\mathrm{H} 3$ were used as a loading control for the cytoplasmic and nuclear fractions, respectively. (B) The quantitative densitometric analysis of Wee-1 and pCDK2 T14/Y15 band intensities was determined in the cytoplasmatic and nuclear fractions for both with Image J software and expressed as fold change over the appropriate housekeeping gene. $\left.{ }^{*} p<0.1 ;{ }^{* *} p<0.001\right)$.

\subsection{Programmed Cell Death in HEp-2 Cells following DOX, GCD and GCD@DOX Treatment}

The apoptotic process represents a programmed cell death (PCD) mechanism that normally provides homeostatic maintenance and cell survival [43]. An unbalanced apoptotic activity is associated with the onset of injuries and several pathologies. In cancer disease, low levels of apoptosis provoke an accumulation of malignant cells and also depend on faulty cellular pathways [44-46]. The activation of apoptosis is characterised by specific biochemical and morphological changes such as apoptotic body formation, chromatin condensation and nuclear fragmentation. First of all, we studied the apoptotic process by analysing the cleavage of poly(ADP-ribose) polymerase-1 (PARP), following antitumour drug intracellular delivery [47]. HEp-2 cells were untreated or treated with $25 \mu \mathrm{g} / \mathrm{mL}$ of GCD@DOX for $24 \mathrm{~h}, 48 \mathrm{~h}$ and $72 \mathrm{~h}$. Free DOX $(1.25 \mu \mathrm{g} / \mathrm{mL})$ and GCD $(25 \mu \mathrm{g} / \mathrm{mL})$ were used as controls. The cleaved PARP-1 expression is shown in Figure 4A and graphically reported in Figure 4B. The Western blot analysis reported the cleavage of PARP following treatment with free DOX starting from $24 \mathrm{~h}$ post-exposure (Figure $4 \mathrm{~A}$ lanes $3,7,11$ ). Con- 
versely, GCD@DOX treatment led to an accumulation of cleaved PARP at $72 \mathrm{~h}(p<0.05)$ (Figure 4A lane 12) indicating a slow release of the drug by the carrier. No significant differences were observed between the GCD-treated and untreated cells, suggesting that the graphene carrier does not affect the cleavage of PARP. In addition, we observed the morphological changes related to apoptotic activation. The cells were first stained with acridine orange $(\mathrm{AO})$, which permeates all cells and makes the nuclei appear green, and then observed on a fluorescence microscope detecting the green emission [48]. The acridine orange-negative cells with a normal green nucleus and homogeneous chromatin distribution were detected in untreated samples (Figure 4C(I)). A limited number of cells with condensed or fragmented chromatin in the green nucleus, debris particles and formation of apoptotic bodies were observed only after GCD@DOX exposure (Figure 4C(III)). DOX treatment led to rounded cellular phenotype $72 \mathrm{~h}$ post-exposure not strictly related to typical morphological features of apoptosis (Figure 4C(II)).

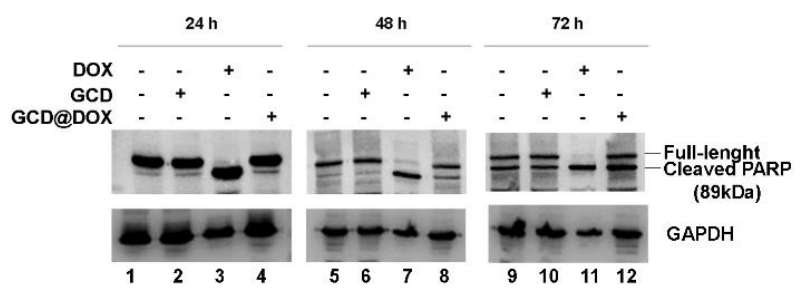

c

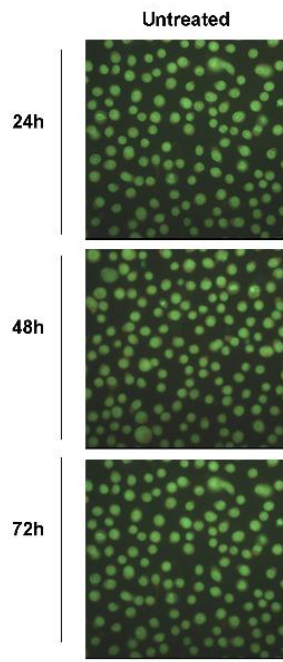

I

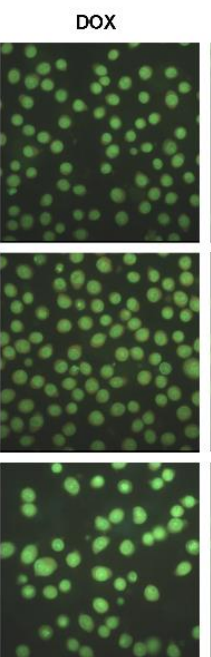

II

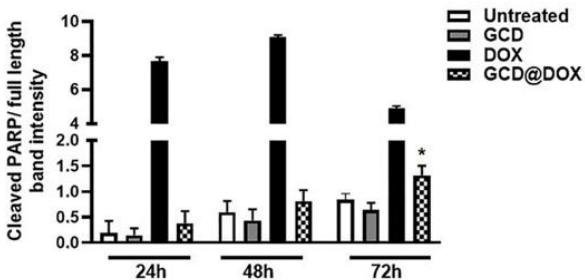

Figure 4. Monitoring of apoptosis in HEp-2 cells following DOX, GCD and GCD@DOX treatment. HEp-2 cells were untreated and treated with $1.25 \mu \mathrm{g} / \mathrm{mL}$ of DOX and $25 \mu \mathrm{g} / \mathrm{mL}$ of GCD@DOX and GCD and collected at $24 \mathrm{~h}, 48 \mathrm{~h}$ and $72 \mathrm{~h}$ post-treatment. (A,B) The Western blot analysis was performed to detect PARP protein expression. The protein bands were visualised by using Immobilon Classico Western HRP substrate (Merk, Millipore) and captured using a ChemiDoc Touch Imaging System (Bio-Rad). The quantitative densitometry analysis of cleaved PARP/full length band intensity was performed by using ImageJ software and is graphically represented in (B) using GraphPad Prism 6 software (GraphPad Software, San Diego, CA, USA). ${ }^{*} p<0.05$, compared with the GCD treated cells. (C) The morphological analysis of apoptotic cells was performed following staining with the fluorescent DNA-binding dyes acridine orange, at $24 \mathrm{~h}, 48 \mathrm{~h}$ and $72 \mathrm{~h}$ post-treatment (I: untreated; II: DOX; III: GCD@DOX) and visualised by fluorescence microscope (Leitz, Wetzlar, Germany) (magnification, 63×). 


\subsection{Monitoring of Autophagy following GCD@DOX and DOX Treatment}

In general, anti-cancer therapy promotes the simultaneous activation of different death signals in order to beat heterogeneous tumour cell populations. In particular, the autophagic mechanism degrades damaged cellular components, recycles cellular organelles, and protects cells from several types of stress, maintaining genomic integrity [49]. However, it is well known that autophagy plays a dual role in cancer development, as either a tumour suppressor for inhibiting tumour progression, or as a cell survival mechanism for promoting tumour growth. For example, increased autophagy and diminished apoptosis were found in DOX-resistant multiple myeloma RPMI8226/DOX cells. Indeed, Pan and collaborators demonstrated that autophagy has a protective role in cancer cells, which results in decreased sensitivity to DOX [50]. To investigate the autophagy process following GCD@DOX exposure, we monitored autophagosomes formation using a genetic approach and quantified the expression of key regulators of autophagy. Autophagy is a dynamic multistep process, regulated by more than 30 autophagy proteins (ATGs), which consists of the formation of autophagosomes, the fusion of the autophagosome with the lysosome to form the autolysosome, and the degradation of the contents in the autolysosome [51-53]. During this process, microtubule-associated protein 1A/1B light chain 3 (LC3-I) is generated by proteolytic cleavage of pro-LC3 and conjugated to phosphatidylethanolamine (PE) to form LC3-II. LC3-II is recruited and incorporated onto the autophagosomal membrane and interacts with the Sequestosome1/p62 (SQSTM1) protein. The accumulation of LC3-II is correlated with autophagosome synthesis and, together with the monitoring of p62 degradation, describes the ongoing autophagosome maturation process $[33,54,55]$. The analysis of the expression levels of LC3-II detected through immunoblot (Figure 5) showed distinct bands for pro-LC3, LC3-I and LC3-II at $24 \mathrm{~h}, 48 \mathrm{~h}$ and $72 \mathrm{~h}$ in untreated cells (Figure 5 lanes 1,5,8). The LC3-II/LC3-I ratio was calculated on the basis of a densitometric analysis of both bands and is presented in a simplified form in Figure 5B. The results show an accumulation of LC3-II/LC3-I after $24 \mathrm{~h}$ and $48 \mathrm{~h}$ of DOX exposure (Figure 5A,B) and low p62 levels at all considered times (Figure 5C). Conversely, high levels of LC3-II/LC3-I and p62 were detected after GCD@DOX treatment at $72 \mathrm{~h}$ and $48 \mathrm{~h}$, respectively. Any significant effect on the LC3-II accumulation occurred as a result of GCD exposure over time, or was otherwise due to increased p62 levels. The results showed an increase in the LC3-II pool in comparison to LC3-I by DOX exposure as a sign of autophagy induction and a reduction of p62 levels. A high level of LC3-II was belatedly $(72 \mathrm{~h})$ detected after GCD@DOX treatment in a GCD-independent manner and without tending to p62 degradation. This indicated that GCD@DOX exposure was correlated with an increased number of autophagosomes, indicating the activation of autophagy. In order to track different stages of autophagy and verify whether the autophagosome maturation process evolved into endosome or lysosome fusion, the mRFP-GFP tandem fluorescent-tagged LC3 assay was employed. The double-tagged LC3B was used to differentially label the autophagosomes and autolysosomes due to the different $\mathrm{pH}$ stability of both probes. In fact, differential quenching of the fluorescence was emitted by the red (mRFP) and green (GFP) proteins in the lysosomal acidic compartment [56]. The graphical representation of mRFP-GFP tandem fluorescent-tagged LC3 is shown in Figure 6A. Briefly, autophagosomes appear as yellow dots $\left(\mathrm{GFP}^{+} / \mathrm{RFP}^{+}\right)$, because both tags emit overlapping fluorescent light. Conversely, the autolysosomes are red dots $\left(\mathrm{GFP}^{-} / \mathrm{RFP}^{+}\right)$, because the GFP fluorescence, unstable in the acidic lysosome environment, is lost. Therefore, HEp-2 cells were transiently transfected for $48 \mathrm{~h}$ with mRFP-GFPLC3 plasmid and $24 \mathrm{~h}$ after transfection were untreated and treated with $1.25 \mu \mathrm{g} / \mathrm{mL}$ of DOX and $25 \mu \mathrm{g} / \mathrm{mL}$ of GCD@DOX, collected, and analysed with confocal microscopy. DOX has an intrinsic bright fluorescence that diffuses into the cells and an emission signal at 595nm. The results in Figure 6B,C show that: (i) in untreated cells, the number of green and red dots overlaps and represents the basal autophagy level. (ii) In DOX-treated cells, about 30\% of red dots were detected. (iii) In GCD@DOX-treated cells, about $50 \%$ of the red dots were detected. These findings suggest that the exposure 
to DOX and GCD@DOX significantly triggers the clear accumulation of autolysosomes, GFP-RFP + LC3, and indicates the activation of the autophagy process.

A

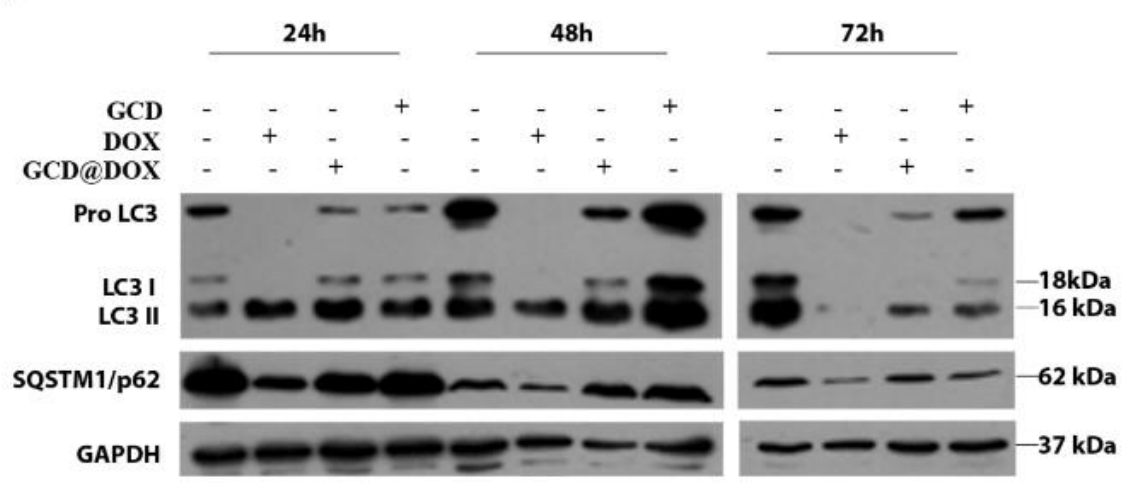

B
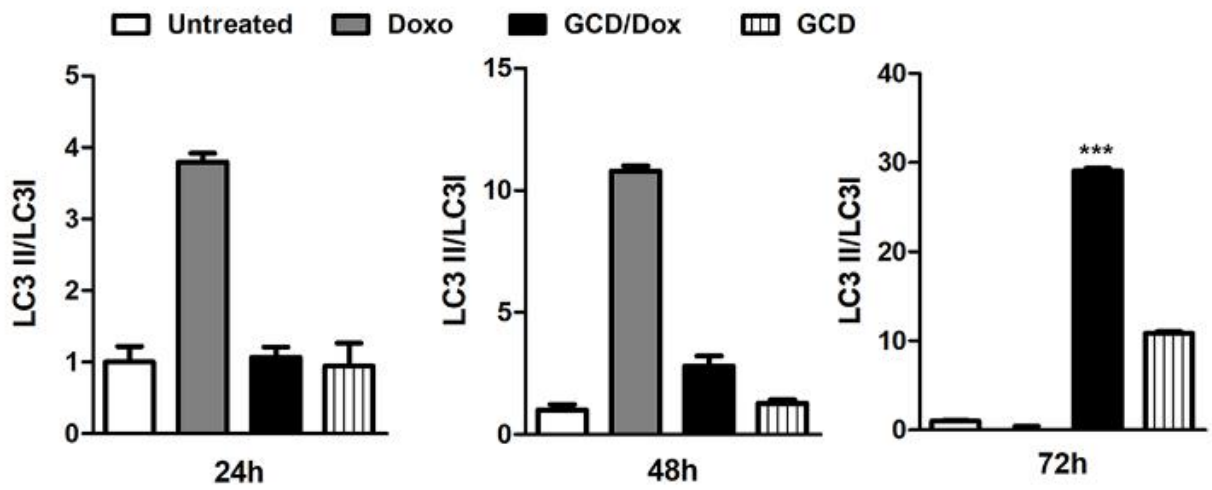

C
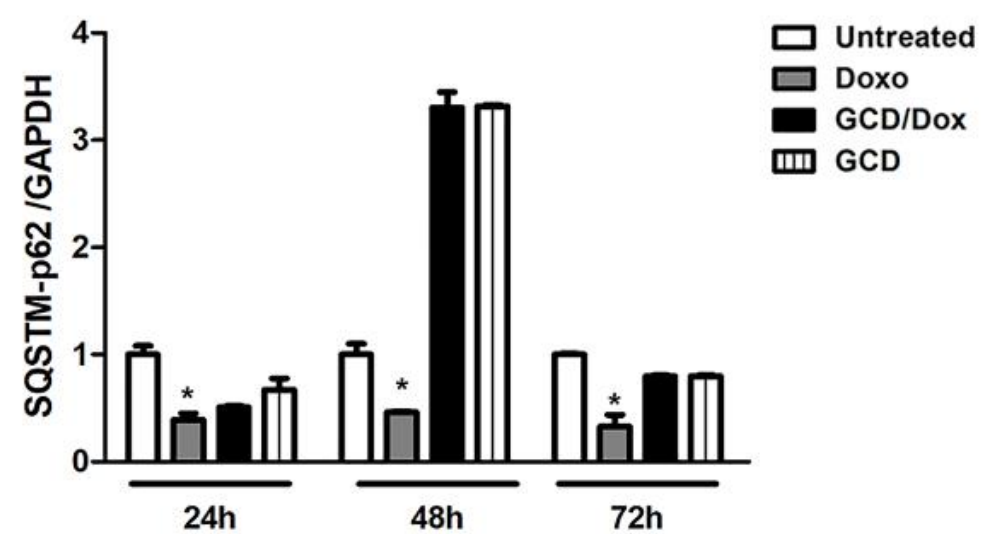

而 GCD

Figure 5. Parallel monitoring of LC3-I, LC3-II and SQSTM-p62 autophagy-related protein expression in HEp-2 cells treated with GCD@DOX and DOX. (A) Immunoblot and quantification of LC3-I, LC3-II and SQSTM-p62 in HEp-2 cells untreated or treated with GCD@DOX, DOX and GCD for the indicated times. (B,C) The graphs show (mean \pm SD) LC3-II/LC3-I ratios of each treatment normalised to the LC3-II/LC3-I ratio of control-untreated cells for each experiment. Statistical significance was tested by one-way ANOVA analysis assay in triplicate. ${ }^{* *} p<0.001$ and ${ }^{*} p<0.05$ indicate significant changes vs. control. 
A

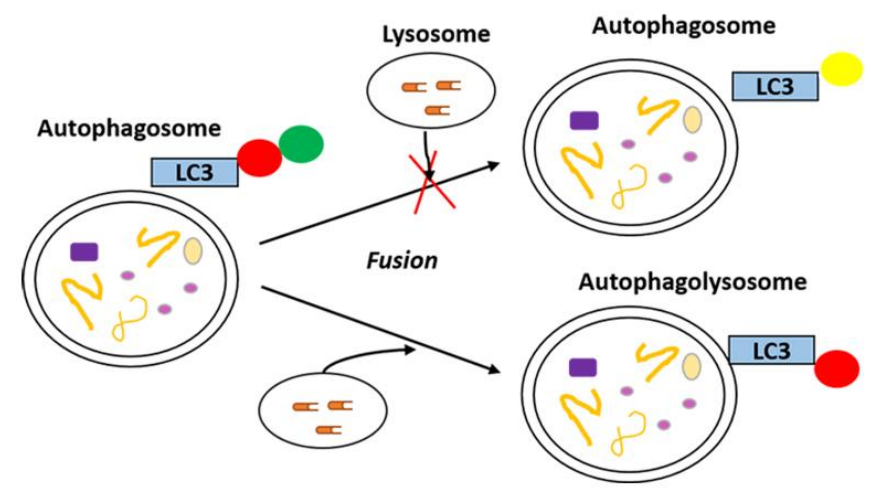

B

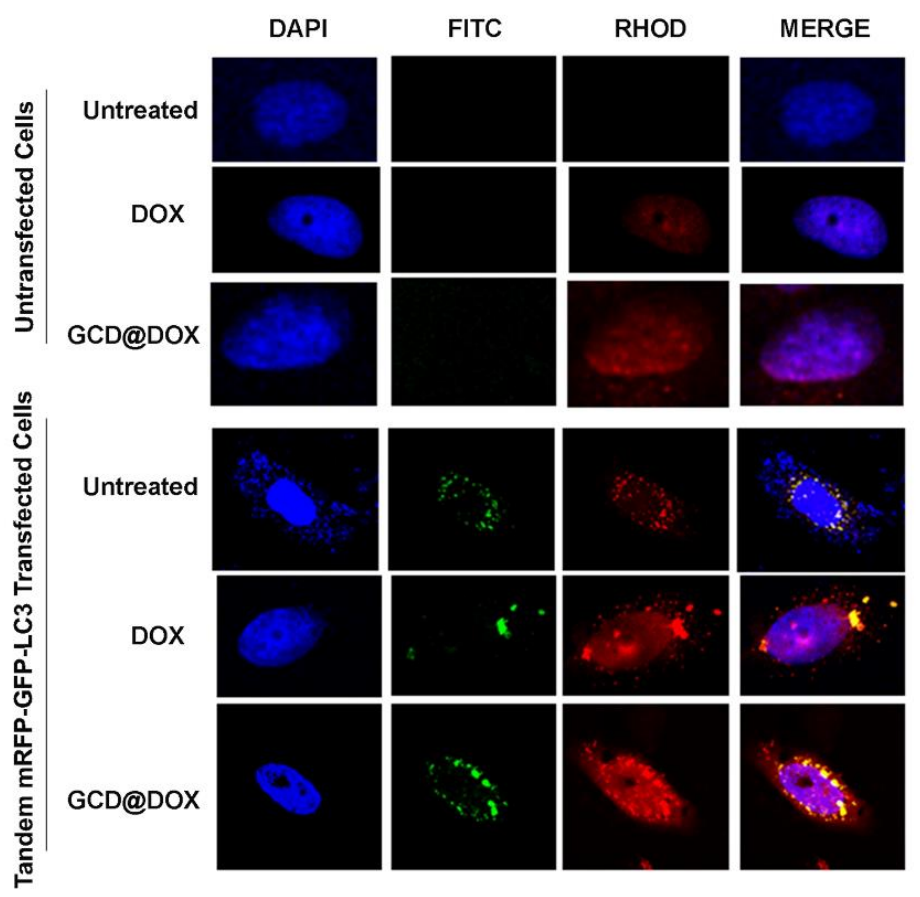

C

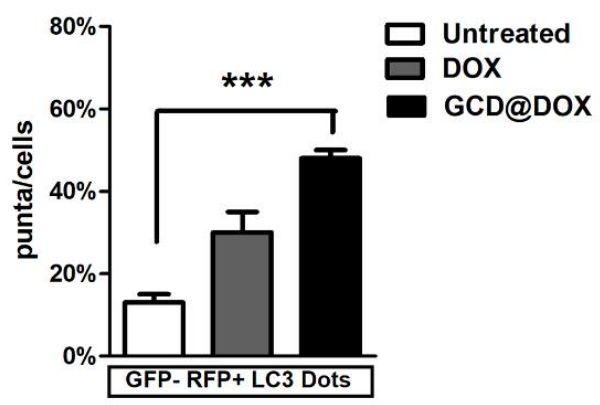

Figure 6. Monitoring of the double-tagged LC3 by mRFP-GFP-LC3 tandem fluorescent protein. (A) Graphical representation of mRFP-GFP-LC3 tandem. (B) Representative confocal images of HEp-2 cells untransfected and transiently transfected with mRFP-GFP tandem fluorescent-tagged LC3 and untreated or treated with DOX $(1.25 \mu \mathrm{g} / \mathrm{mL})$ and GCD@DOX $(25 \mu \mathrm{g} / \mathrm{mL})$ for $48 \mathrm{~h}$ (magnification, 63X). (C) Quantification of $\mathrm{GFP}^{-} / \mathrm{RFP}^{+} / \mathrm{LC} 3$ dots represented as percentage (\%) in HEp-2 untreated and treated with DOX and GCD@DOX. Statistical significance was tested by one-way ANOVA analysis assay in triplicate $(* * *<0.001)$. 


\section{Discussion}

Many studies have recently pointed out the efficiency of DOX loaded into nanoparticles, which is able to overcome the limitations of conventional treatments in cancer therapy $[57,58]$. DOX exerts an anti-cancer effect through intercalation into the DNA, inducing single- and double-strand breaks in the DNA [59]. Additionally, it interacts specifically with the inner mitochondrial membrane, leading to the production of reactive oxygen species (ROS) [60]. To date, chemotherapeutic treatment with DOX is associated with undesirable multi-organ toxicities, including liver, cardiac, neuronal, and muscle toxicity, hepatorenal profile alterations, and systemic inflammation [61,62]. Thus, its clinical uses have been restricted to low dosages. Therefore, DOX-based nanoformulations have been studied for their anticancer effect and for their ability to evade chemoresistance and DOX toxicity. Indeed, Andreopoulou and collaborators found lower values of cardiac toxicity in therapy with liposomal DOX plus Trastuzumab for metastatic breast cancer [63]. Modification of DOX with ligands, lipid-polymer hybrid nanoparticles, and liposomes is anticipated to improve the transport of DOX into tumour cells, as well as limiting its toxicity and activating anti-cancer intracellular signalling [64-66]. Recently, our group examined the stability and biological behaviour of an in vitro system of GCD@DOX on the murine C26 cell line and on the human HEp-2 cell line [18]. Changes in the expression of some genes associated with angiogenesis, such as extracellular matrix modification (ECM) and tumour metastasis, were found. In particular, GCD@DOX induced a strong downregulation of genes that can be involved in tumorigenesis, including ST14, PLAUR, SP1, SF3A3, ITGB2, GSN, BMP5, TNFSF12, and AKT1. Otherwise, GCD alone affects four genes with an opposite trend compared to DOX loaded on GCD (VIM, TNFSF12, BICC1, SRPK2). Graphene affects cell biology in a variety of modes, and some effects can be beneficial; for example, increased VIM expression is correlated with resistance and poor outcome treatment in patients with different tumours. The detrimental increase in VIM expression induced by DOX could be softened by GCD-induced VIM down-regulation. This study provides further insights into the intracellular targets of DOX, which are involved in the clearance of tumour cells. In particular, we characterised graphene-mediated signalling and its role in DOX release, analysing the expression of $\mathrm{p} 53$ protein and the p53-related pathways. p53 plays a crucial role in supporting DNA repair by arresting the cell cycle, regulating apoptosis, and controlling autophagy [67]. Therefore, we reported that DOX and GCD@DOX induce p53 accumulation (Figure 2). The p53-dependent upregulation of the cell cycle inhibitor p21 occurs belatedly following GCD@DOX compared to the free DOX treatment, suggesting that GCD controls DOX release over time. While p53 and p21 are considered mediators of G0/G1 cell cycle arrest, Wee-1 blocks G2/M transition. Wee-1 is an inhibitory kinase that catalyses the phosphorylation of tyrosine 15 (Y15) on CDK, rendering it inactive and blocking CDK-cyclin interaction and cell cycle progression [41,42]. We found that DOX treatment triggers the reduction of Wee-1 protein expression, unlike GCD and GCD@DOX, whose levels are comparable over time to endogenous expression (Figure 3). The combined decrease of Wee-1 and accumulation of pCDK (T14/Y15) by DOX is consistent with the inhibition of Wee- 1 in cancer treatment reported in previous studies [41]. Elbæk and collaborators reported that CDK drives the proteasomal degradation of Wee-1, leading to its decrease. Additionally, the inhibition of Wee-1 overrides the cell cycle arrest and results in mitotic entry [42]. This fact could explain the genotoxic behaviour induced by chemotherapeutic drugs, and emphasises the importance of nanotechnology in drug delivery. Additionally, p53 can promote non-apoptotic cell death via p53-PARP crosstalk [68]. The PARP activation can be attributed to ROS generation induced by cytotoxic drugs [69]. Our findings report a cleavage of PARP by DOX within $72 \mathrm{~h}$ of treatment. Unlike, GCD@DOX induces a late cleavage of PARP, which can be indicative of a less toxic effect as a result of controlled drug release (Figure 4). Additionally, the existence of the p21/PARP-1 axis has been reported to be involved in DNA damage and repair [70]. In particular, p21 is sequestered by PARP-1, facilitating DNA repair mechanisms [71]. For this reason, the PARP-1 cleavage after DOX exposure, as shown in Figure 4A, does not 
match perfectly with the apoptosis induction reported through acridine orange staining (Figure 4C). Chromatin condensation, debris particles, and formation of apoptotic bodies, hallmarks of apoptosis, were poorly detected after GCD and GCD@DOX treatment and were potentially related to mechanical stress induced by graphene uptake, as indicated by the low toxicity levels detected at $24 \mathrm{~h}$ (Figure 1 ). In agreement with the literature, our data showed a cytotoxic effect of DOX after $48 \mathrm{~h}$ of exposure and a late recovery at $72 \mathrm{~h}$, which was potentially linked to drug metabolism [72]. Conversely, GCD and GCD@DOX induced early weak toxicity at $24 \mathrm{~h}$, but no considerable effect was detected over time. This phenomenon underlines the temporal biocompatibility of the nano-platform. Additionally, these differences in cytotoxicity could be related to the accumulation and efflux of the drug or its metabolites following free or graphene-mediated delivery. Together with the role of p53 in inducing apoptosis and growth arrest, a non-canonical p53 function has been reported [73,74]. Duan and collaborators reported that p53 activates the autophagy process through the inhibition of mTOR [73]. Autophagy is a catabolic process needed to maintain homeostasis and survival through the removal and recycling of unwanted cellular materials. Although autophagy, unlike apoptosis, which is a clear mechanism of cell death, represents a cellular pro-survival pathway [74], different studies have identified them as independent processes with interconnected cell death mechanisms [24,75-77]. Autophagy is characterised by the formation of double membrane-bound structures wrapping organelles, known as autophagosomes, which fuse with lysosomes to form autolysosomes and degrade the absorbed materials [52]. A set of established criteria is necessary to observe and validate autophagy induction. The localisation of LC3-II on the cytosolic surface of autophagosomes is widely used as a marker of autophagy [53-55]. Here, the clear accumulation of autolysosomes, GFP-RFP + LC3, was reported after exposure to DOX and GCD@DOX. This increase, observed through tandem fluorescent-tagged LC3 (mRFP-EGFP-LC3) assay, was statistically significant (Figure 6). In parallel with monitoring LC3-II, tracking the conversion of LC3-I to LC3-II and the degradation of p62, which are factors indicative of autophagic activity, are necessary for monitoring autophagic flux [55,78]. We showed an increase in the LC3-II pool in comparison to LC3-I with DOX exposure, along with a reduction in p62 levels (Figure 5). Conversely, GCD@DOX treatment accumulates LC3-II belatedly, without degrading p62, and in a graphene-independent manner. Recent studies have demonstrated that autophagy induced by chemotherapeutic drugs may promote the resistance of cancer cells to drugs, together with decreased apoptosis [50,79]. Our results indicate that DOX treatment activates the autophagy flux and maintains it over time. This finding, combined with the cell cycle regulation reported previously, may support the hypothesis that a combined effect of both processes could be useful for limiting the existence and persistence of heterogeneous tumour cell populations. Otherwise, GCD@DOX activates autophagy, but rather than promoting the immediate degradation of cellular substrates useful for tumour growth, it supports the recycling of DOX, limiting its toxicity. Indeed, because the drugs used in chemotherapy result in highly deleterious and often life-threatening side effects, a controlled drug delivery system, mediated by a graphene-based platform, could target sub-cellular sites, reducing cytotoxicity.

\section{Conclusions}

Overall, the present investigation allowed us to characterise some of the cellular pathways commonly recruited in nanomaterial treatments such as autophagy. Our results showed that the intracellular delivery of DOX mediated by the graphene platform GCD activates the p53 pathway, induces apoptosis signalling, and sustains the removal and recycling of DOX by activation of autophagy. The developed graphene-based drug delivery tool could offer an approach to the intracellular delivery of DOX, maximising its therapeutic effect and limiting its toxicity. Nevertheless, a deeper understanding of GCD-autophagy interaction at the mechanistic and functional level is needed before these findings can be exploited to increase the effectiveness of GCD in cancer therapeutics and drug delivery. 


\begin{abstract}
Author Contributions: The manuscript was written through contributions of all authors. A.P. and M.T.S. supervised the project. A.P., A.M., A.S., R.P. and M.T.S. developed the concepts. R.P. wrote the paper and performed the experiments. G.N. synthesised graphene materials. M.M.-P. performed the viability assay. R.P., M.T.S., A.S., T.V., A.M. and A.P. performed review \& editing. All authors discussed the results and commented on the manuscript. M.T.S. contributed to funding acquisition. All authors have read and agreed to the published version of the manuscript.
\end{abstract}

Funding: This work was aided by a grant from University of Messina, Research \& Mobility 2016 Project (project code: RES AND MOB 2016 Sciortino) and the University of Messina FFABR 2019-Sciortino Project.

Institutional Review Board Statement: Not applicable.

Informed Consent Statement: Not applicable.

Data Availability Statement: Not applicable.

Conflicts of Interest: The authors declare no conflict of interest.

\title{
References
}

1. Hejmady, S.; Pradhan, R.; Alexander, A.; Agrawal, M.; Singhvi, G.; Gorain, B.; Tiwari, S.; Kesharwani, P.; Dubey, S.K. Recent Advances in Targeted Nanomedicine as Promising Antitumor Therapeutics. Drug Discov. Today 2020, 25, 2227-2244. [CrossRef] [PubMed]

2. Thakkar, S.; Sharma, D.; Kalia, K.; Tekade, R.K. Tumor Microenvironment Targeted Nanotherapeutics for Cancer Therapy and Diagnosis: A Review. Acta Biomater. 2020, 101, 43-68. [CrossRef]

3. Piperno, A.; Sciortino, M.T.; Giusto, E.; Montesi, M.; Panseri, S.; Scala, A. Recent Advances and Challenges in Gene Delivery Mediated by Polyester-Based Nanoparticles. Int. J. Nanomed. 2021, 16, 5981-6002. [CrossRef]

4. Bahrami, B.; Hojjat-Farsangi, M.; Mohammadi, H.; Anvari, E.; Ghalamfarsa, G.; Yousefi, M.; Jadidi-Niaragh, F. Nanoparticles and Targeted Drug Delivery in Cancer Therapy. Immunol. Lett. 2017, 190, 64-83. [CrossRef]

5. Montellano, A.; Da Ros, T.; Bianco, A.; Prato, M. Fullerene $\mathrm{C}_{60}$ as a Multifunctional System for Drug and Gene Delivery. Nanoscale 2011, 5, 4035-4041. [CrossRef]

6. Yang, K.; Zhang, S.; Zhang, G.; Sun, X.; Lee, S.T.; Liu, Z. Graphene in Mice: Ultrahigh In Vivo Tumor Uptake and Efficient Photothermal Therapy. Nano Lett. 2010, 10, 3318-3323. [CrossRef] [PubMed]

7. Mazzaglia, A.; Scala, A.; Sortino, G.; Zagami, R.; Zhu, Y.; Sciortino, M.T.; Pennisi, R.; Pizzo, M.M.; Neri, G.; Grassi, G.; et al. Intracellular Trafficking and Therapeutic Outcome of Multiwalled Carbon Nanotubes Modified with Cyclodextrins and Polyethylenimine. Colloids Surf B Biointerfaces 2018, 163, 55-63. [CrossRef] [PubMed]

8. Piperno, A.; Scala, A.; Mazzaglia, A.; Neri, G.; Pennisi, R.; Sciortino, M.T.; Grassi, G. Cellular Signaling Pathways Activated by Functional Graphene Nanomaterials. Int. J. Mol. Sci. 2018, 19, 3365. [CrossRef]

9. Tadyszak, K.; Wychowaniec, J.K.; Litowczenko, J. Biomedical Applications of Graphene-Based Structures. Nanomaterials 2018, 8, 944. [CrossRef]

10. Li, R.Q.; Ren, Y.; Liu, W.; Pan, W.; Xu, F.J.; Yang, M. MicroRNA-Mediated Silence of Onco-lncRNA MALAT1 in Different ESCC Cells via Ligand-Functionalized Hydroxyl-Rich Nanovectors. Nanoscale 2017, 16, 2521-2530. [CrossRef]

11. Zakeri, A.; Kouhbanani, M.A.J.; Beheshtkhoo, N.; Beigi, V.; Mousavi, S.M.; Hashemi, S.A.R.; Karimi Zade, A.; Amani, A.M.; Savardashtaki, A.; Mirzaei, E.; et al. Polyethylenimine-Based Nanocarriers in Co-Delivery of Drug and Gene: A Developing Horizon. Nano Rev. Exp. 2018, 3, 1488497. [CrossRef] [PubMed]

12. Barua, S.; Ramos, J.; Potta, T.; Taylor, D.; Huang, H.C.; Montanez, G.; Rege, K. Discovery of Cationic Polymers for Non-Viral Gene Delivery Using Combinatorial Approaches. Comb. Chem. High Throughput Screen. 2011, 14, 908-924. [CrossRef] [PubMed]

13. Hasanzadeh, L.; Darroudi, M.; Ramezanian, N.; Zamani, P.; Aghaee-Bakhtiari, S.H.; Nourmohammadi, E.; Kazemi Oskuee, R. Polyethylenimine-Associated Cerium Oxide Nanoparticles: A Novel Promising Gene Delivery Vector. Life Sci. 2019, $232,116661$. [CrossRef] [PubMed]

14. Kasprzak, A.; Poplawska, M. Recent Developments in the Synthesis and Applications of Graphene-Family Materials Functionalized with Cyclodextrins. Chem. Commun. (Camb.) 2018, 54, 8547-8562. [CrossRef] [PubMed]

15. Neri, G.; Scala, A.; Barreca, F.; Fazio, E.; Mineo, P.G.; Mazzaglia, A.; Grassi, G.; Piperno, A. Engineering of Carbon Based Nanomaterials by Ring-Opening Reactions of a Reactive Azlactone Graphene Platform. Chem. Commun. (Camb.) 2015, 51, 4846-4849. [CrossRef]

16. Neri, G.; Scala, A.; Fazio, E.; Mineo, P.G.; Rescifina, A.; Piperno, A.; Grassi, G. Repurposing of Oxazolone Chemistry: Gaining Access to Functionalized Graphene Nanosheets in a Top-Down Approach from Graphite. Chem. Sci. 2015, 6, 6961-6970. [CrossRef]

17. Piperno, A.; Mazzaglia, A.; Scala, A.; Pennisi, R.; Zagami, R.; Neri, G.; Torcasio, S.M.; Rosmini, C.; Mineo, P.G.; Potara, M.; et al. Casting Light on Intracellular Tracking of a New Functional Graphene-Based MicroRNA Delivery System by FLIM and Raman Imaging. ACS Appl. Mater. Interfaces 2019, 11, 46101-46111. [CrossRef] 
18. Caccamo, D.; Currò, M.; Ientile, R.; Verderio, E.A.; Scala, A.; Mazzaglia, A.; Pennisi, R.; Musarra-Pizzo, M.; Zagami, R.; Neri, G.; et al. Intracellular Fate and Impact on Gene Expression of Doxorubicin/Cyclodextrin-Graphene Nanomaterials at Sub-Toxic Concentration. Int. J. Mol. Sci. 2020, 21, 4891. [CrossRef]

19. Borandeh, S.; Abdolmaleki, A.; Abolmaali, S.S.; Tamaddon, A.M. Synthesis, Structural and In-Vitro Characterization of $\beta$-Cyclodextrin Grafted L-Phenylalanine Functionalized Graphene Oxide Nanocomposite: A Versatile Nanocarrier for pH-Sensitive Doxorubicin Delivery. Carbohydr. Polym. 2018, 201, 151-161. [CrossRef]

20. Yang, X.; Zhang, X.; Liu, Z.; Ma, Y.; Huang, Y.; Chen, Y. High-Efficiency Loading and Controlled Release of Doxorubicin Hydrochloride on Graphene Oxide. J. Phys. Chem. C 2008, 112, 17554-17558. [CrossRef]

21. Swiech, O.; Mieczkowska, A.; Chmurski, K.; Bilewicz, R. Intermolecular Interactions between Doxorubicin and $\beta$-Cyclodextrin 4-Methoxyphenol Conjugates. J. Phys. Chem. B. 2012, 116, 1765-1771. [CrossRef]

22. Pennetta, C.; Floresta, G.; Graziano, A.C.E.; Cardile, V.; Rubino, L.; Galimberti, M.; Rescifina, A.; Barbera, V. Functionalization of Single and Multi-Walled Carbon Nanotubes with Polypropylene Glycol Decorated Pyrrole for the Development of Doxorubicin Nano-Conveyors for Cancer Drug Delivery. Nanomaterials 2020, 10, 1073. [CrossRef]

23. Ou, L.; Lin, S.; Song, B.; Liu, J.; Lai, R.; Shao, L. The Mechanisms of Graphene-Based Materials-Induced Programmed Cell Death: A Review of Apoptosis, Autophagy, and Programmed Necrosis. Int. J. Nanomed. 2017, 12, 6633-6646. [CrossRef]

24. Burnett, M.; Abuetabh, Y.; Wronski, A.; Shen, F.; Persad, S.; Leng, R.; Eisenstat, D.; Sergi, C. Graphene Oxide Nanoparticles Induce Apoptosis in Wild-Type and CRISPR/Cas9-IGF/IGFBP3 Knocked-Out Osteosarcoma Cells. J. Cancer 2020, 11, 5007-5023. [CrossRef] [PubMed]

25. Zhang, Y.; Ali, S.F.; Dervishi, E.; Xu, Y.; Li, Z.; Casciano, D.; Biris, A.S. Cytotoxicity Effects of Graphene and Single-Wall Carbon Nanotubes in Neural Phaeochromocytoma-Derived PC12 Cells. ACS Nano 2010, 4, 3181-3186. [CrossRef] [PubMed]

26. Yang, K.; Wan, J.; Zhang, S.; Zhang, Y.; Lee, S.T.; Liu, Z. In Vivo Pharmacokinetics, Long-Term Biodistribution, and Toxicology of PEGylated Graphene in Mice. ACS Nano 2011, 5, 516-522. [CrossRef] [PubMed]

27. Kang, Y.; Liu, J.; Wu, J.; Yin, Q.; Liang, H.; Chen, A.; Shao, L. Graphene Oxide and Reduced Graphene Oxide Induced Neural Pheochromocytoma-Derived PC12 Cell Lines Apoptosis and Cell Cycle Alterations via the ERK Signaling Pathways. Int. J. Nanomed. 2017, 12, 5501-5510. [CrossRef]

28. Mailänder, V.; Landfester, K. Interaction of Nanoparticles with Cells. Biomacromolecules 2009, 10, 2379-2400. [CrossRef]

29. Ji, X.; Xu, B.; Yao, M.; Mao, Z.; Zhang, Y.; Xu, G.; Tang, Q.; Wang, X.; Xia, Y. Graphene Oxide Quantum Dots Disrupt Autophagic Flux by Inhibiting Lysosome Activity in GC-2 and TM4 Cell Lines. Toxicology 2018, 410, 169. [CrossRef]

30. Zhang, B.; Wei, P.; Zhou, Z.; Wei, T. Interactions of Graphene with Mammalian Cells: Molecular Mechanisms and Biomedical Insights. Adv. Drug Deliv. Rev. 2016, 105, 145-162. [CrossRef]

31. Colao, I.; Pennisi, R.; Venuti, A.; Nygårdas, M.; Heikkilä, O.; Hukkanen, V.; Sciortino, M.T. The ERK-1 Function Is Required for HSV-1-Mediated G1/S Progression in HEP-2 Cells and Contributes to Virus Growth. Sci. Rep. 2017, 7, 9176. [CrossRef]

32. Mastino, A.; Sciortino, M.T.; Medici, M.A.; Perri, D.; Ammendolia, M.G.; Grelli, S.; Amici, C.; Pernice, A.; Guglielmino, S. Herpes Simplex Virus 2 Causes Apoptotic Infection in Monocytoid Cells. Cell Death Differ. 1997, 4, 629-638. [CrossRef]

33. Kimura, S.; Noda, T.; Yoshimori, T. Dissection of the Autophagosome Maturation Process by a Novel Reporter Protein, Tandem Fluorescent-Tagged LC3. Autophagy 2007, 3, 452-460. [CrossRef] [PubMed]

34. Matt, S.; Hofmann, T.G. The DNA Damage-Induced Cell Death Response: A Roadmap to Kill Cancer Cells. Cell Mol. Life Sci. 2016, 73, 2829-2850. [CrossRef] [PubMed]

35. De Zio, D.; Cianfanelli, V.; Cecconi, F. New Insights into the Link between DNA Damage and Apoptosis. Antioxid. Redox Signal. 2013, 19, 559-571. [CrossRef]

36. Williams, A.B.; Schumacher, B. p53 in the DNA-Damage-Repair Process. Cold Spring Harb. Perspect. Med. 2016, 6, a026070. [CrossRef]

37. Wiman, K.G. p53 Talks to PARP: The Increasing Complexity of p53-Induced Cell Death. Cell Death Differ. 2013, 20, 1438-1439. [CrossRef]

38. Michieli, P.; Chedid, M.; Lin, D.; Pierce, J.H.; Mercer, W.E.; Givol, D. Induction of WAF1/CIP1 by a p53-Independent Pathway. Cancer Res. 1994, 54, 3391-3395.

39. Karimian, A.; Ahmadi, Y.; Yousefi, B. Multiple Functions of p21 in Cell Cycle, Apoptosis and Transcriptional Regulation After DNA Damage. DNA Repair (Amst.) 2016, 42, 63-71. [CrossRef] [PubMed]

40. Barnum, K.J.; O'Connell, M.J. Cell Cycle Regulation by Checkpoints. Methods Mol. Biol. 2014, 1170, 29-40.

41. Elbæk, C.R.; Petrosius, V.; Sørensen, C.S. WEE1 Kinase Limits CDK Activities to Safeguard DNA Replication and Mitotic Entry. Mutat. Res 2020, 819-820, 111694. [CrossRef] [PubMed]

42. Watanabe, N.; Broome, M.; Hunter, T. Regulation of the Human WEE1Hu CDK Tyrosine 15-Kinase during the Cell Cycle. EMBO J. 1995, 14, 1878-1891. [CrossRef] [PubMed]

43. Elmore, S. Apoptosis: A Review of Programmed Cell Death. Toxicol. Pathol. 2007, 35, 495-516. [CrossRef] [PubMed]

44. Singh, R.; Letai, A.; Sarosiek, K. Regulation of Apoptosis in Health and Disease: The Balancing Act of BCL-2 Family Proteins. Nat. Rev. Mol. Cell Biol. 2019, 20, 175-193. [CrossRef]

45. Goldar, S.; Khaniani, M.S.; Derakhshan, S.M.; Baradaran, B. Molecular Mechanisms of Apoptosis and Roles in Cancer Development and Treatment. Asian Pac. J. Cancer Prev. 2015, 16, 2129-2144. [CrossRef]

46. Fan, T.J.; Han, L.H.; Cong, R.S.; Liang, J. Caspase Family Proteases and Apoptosis. Acta Biochim. Biophys. Sin. 2005, 37, 719-727. [CrossRef]

47. Koh, D.W.; Dawson, T.M.; Dawson, V.L. Mediation of Cell Death by Poly(ADP-Ribose) Polymerase-1. Pharmacol. Res. 2005, 52, 5-14. [CrossRef] 
48. Byvaltsev, V.A.; Bardonova, L.A.; Onaka, N.R.; Polkin, R.A.; Ochkal, S.V.; Shepelev, V.V.; Aliyev, M.A.; Potapov, A.A. Acridine Orange: A Review of Novel Applications for Surgical Cancer Imaging and Therapy. Front. Oncol. 2019, 9, 925. [CrossRef]

49. Parzych, K.R.; Klionsky, D.J. An Overview of Autophagy: Morphology, Mechanism, and Regulation. Antioxid. Redox Signal. 2014, 20, 460-473. [CrossRef]

50. Pan, Y.Z.; Wang, X.; Bai, H.; Wang, C.B.; Zhang, Q.; Xi, R. Autophagy in Drug Resistance of the Multiple Myeloma Cell Line RPMI8226 to Doxorubicin. Genet. Mol. Res. 2015, 14, 5621-5629. [CrossRef]

51. Ueno, T.; Komatsu, M. Monitoring Autophagy Flux and Activity: Principles and Applications. Bioessays 2020, 42, e2000122. [CrossRef]

52. Glick, D.; Barth, S.; Macleod, K.F. Autophagy: Cellular and Molecular Mechanisms. J. Pathol. 2010, 221, 3-12. [CrossRef]

53. Tanida, I.; Minematsu-Ikeguchi, N.; Ueno, T.; Kominami, E. Lysosomal Turnover, but Not a Cellular Level, of Endogenous LC3 Is a Marker for Autophagy. Autophagy 2005, 1, 84-91. [CrossRef]

54. Zhou, C.; Zhong, W.; Zhou, J.; Sheng, F.; Fang, Z.; Wei, Y.; Chen, Y.; Deng, X.; Xia, B.; Lin, J. Monitoring autophagic flux by an improved tandem fluorescent-tagged LC3 (mTagRFP-mWasabi-LC3) reveals that high-dose rapamycin impairs autophagic flux in cancer cells. Autophagy 2012, 8, 1215-1226. [CrossRef]

55. Sritharan, S.; Sivalingam, N. A Comprehensive Review on Time-Tested Anticancer Drug Doxorubicin. Life Sci. 2021, 278, 119527. [CrossRef]

56. Dupont, N.; Orhon, I.; Bauvy, C.; Codogno, P. Autophagy and Autophagic Flux in Tumor Cells. Methods Enzymol. 2014, 543, 73-88.

57. Shafei, A.; El-Bakly, W.; Sobhy, A.; Wagdy, O.; Reda, A.; Aboelenin, O.; Marzouk, A.; El Habak, K.; Mostafa, R.; Ali, M.A.; et al. A Review on the Efficacy and Toxicity of Different Doxorubicin Nanoparticles for Targeted Therapy in Metastatic Breast Cancer. Biomed. Pharmacother. 2017, 95, 1209-1218. [CrossRef]

58. Zainal-Abidin, M.H.; Hayyan, M.; Ngoh, G.C.; Wong, W.F. Doxorubicin Loading on Functional Graphene as a Promising Nanocarrier Using Ternary Deep Eutectic Solvent Systems. ACS Omega 2020, 5, 1656-1668. [CrossRef] [PubMed]

59. Barranco, S.C.; Gerner, E.W.; Burk, K.H.; Humphrey, R.M. Survival and Cell Kinetics Effects of Adriamycin on Mammalian Cells. Cancer Res. 1973, 33, 11-16. [PubMed]

60. Davies, K.J.; Doroshow, J.H. Redox Cycling of Anthracyclines by Cardiac Mitochondria. I. Anthracycline Radical Formation by NADH Dehydrogenase. J. Biol. Chem. 1986, 261, 3060-3067. [CrossRef]

61. Hanna, A.D.; Lam, A.; Tham, S.; Dulhunty, A.F.; Beard, N.A. Adverse Effects of Doxorubicin and Its Metabolic Product on Cardiac RyR2 and SERCA2A. Mol. Pharmacol. 2014, 86, 438-449. [CrossRef] [PubMed]

62. Ryberg, M.; Nielsen, D.L.; Jensen, M.T.; Nielsen, G.; Andersen, P.K. Predictive Factors for the Severity of Congestive Heart Failure after an Epirubicin-Based Treatment for Metastatic Breast Cancer. J. Clin. Oncol. Conf. 2010, 28, 1124. [CrossRef]

63. Andreopoulou, E.; Gaiotti, D.; Kim, E.; Volm, M.; Oratz, R.; Freedberg, R.; Downey, A.; Vogel, C.L.; Chia, S.; Muggia, F. Feasibility and Cardiac Safety of Pegylated Liposomal Doxorubicin Plus Trastuzumab in Heavily Pretreated Patients with Recurrent HER2-Overexpressing Metastatic Breast Cancer. Clin. Breast Cancer 2007, 7, 690-696. [CrossRef] [PubMed]

64. Makwana, V.; Karanjia, J.; Haselhorst, T.; Anoopkumar-Dukie, S.; Rudrawar, S. Liposomal Doxorubicin as Targeted Delivery Platform: Current Trends in Surface Functionalization. Int. J. Pharm. 2021, 593, 120117. [CrossRef]

65. Li, C.; Lai, C.; Qiu, Q.; Luo, X.; Hu, L.; Zheng, H.; Lu, Y.; Liu, M.; Zhang, H.; Liu, X.; et al. Dual-Ligand Modification of PEGylated Liposomes Used for Targeted Doxorubicin Delivery to Enhance Anticancer Efficacy. AAPS PharmSciTech 2019, 20, 188. [CrossRef] [PubMed]

66. Hu, D.; Chen, L.; Qu, Y.; Peng, J.; Chu, B.; Shi, K.; Hao, Y.; Zhong, L.; Wang, M.; Qian, Z. Oxygen-Generating Hybrid Polymeric Nanoparticles with Encapsulated Doxorubicin and Chlorin e6 for Trimodal Imaging-Guided Combined Chemo-Photodynamic Therapy. Theranostics 2018, 8, 1558-1574. [CrossRef] [PubMed]

67. Feroz, W.; Sheikh, A.M.A. Exploring the Multiple Roles of Guardian of the Genome: P53. Egypt J. Med. Hum. Genet. 2020, 21, 49. [CrossRef]

68. Fischbach, A.; Krüger, A.; Hampp, S.; Assmann, G.; Rank, L.; Hufnagel, M.; Stöckl, M.T.; Fischer, J.M.F.; Veith, S.; Rossatti, P.; et al. The C-Terminal Domain of p53 Orchestrates the Interplay between Non-Covalent and Covalent Poly(ADP-Ribosyl)ation of p53 by PARP1. Nucleic Acids Res. 2018, 46, 804-822. [CrossRef]

69. Hocsak, E.; Szabo, V.; Kalman, N.; Antus, C.; Cseh, A.; Sumegi, K.; Eros, K.; Hegedus, Z.; Gallyas, F., Jr.; Sumegi, B.; et al. PARP Inhibition Protects Mitochondria and Reduces ROS Production via PARP-1-ATF4-MKP-1-MAPK Retrograde Pathway. Free Radic. Biol. Med. 2017, 108, 770-784. [CrossRef]

70. Cazzalini, O.; Dona, F.; Savio, M.; Tillhon, M.; Maccario, C.; Perucca, P.; Stivala, L.A.; Scovassi, A.I.; Prosperi, E. p21CDKN1A Participates in Base Excision Repair by Regulating the Activity of Poly(ADP-ribose) Polymerase-1. DNA Repair (Amst.) 2010, 9, 627-635. [CrossRef]

71. Prosperi, E.; Scovassi, I.A. Dynamic Interaction between PARP-1, PCNA and p21waf1/cip1. In Madame Curie Bioscience Database [Internet]; Landes Bioscience: Austin, TX, USA, 2000-2013. Available online: https://www.ncbi.nlm.nih.gov/books/NBK6457 (accessed on 25 November 2021).

72. Bains, O.S.; Szeitz, A.; Lubieniecka, J.M.; Cragg, G.E.; Grigliatti, T.A.; Riggs, K.W.; Reid, R.E. A Correlation between Cytotoxicity and Reductase-Mediated Metabolism in Cell Lines Treated with Doxorubicin and Daunorubicin. J. Pharmacol. Exp. Ther. 2013, 347, 375-387. [CrossRef]

73. Duan, L.; Perez, R.E.; Davaadelger, B.; Dedkova, E.N.; Blatter, L.A.; Maki, C.G. p53-Regulated Autophagy Is Controlled by Glycolysis and Determines Cell Fate. Oncotarget 2015, 6, 23135-23156. [CrossRef]

74. Mrakovcic, M.; Fröhlich, L.F. p53-Mediated Molecular Control of Autophagy in Tumor Cells. Biomolecules 2018, 8, 14. [CrossRef]

75. Yonekawa, T.; Thorburn, A. Autophagy and Cell Death. Essays Biochem. 2013, 55, 105-117. 
76. D'Arcy, M.S. Cell Death: A Review of the Major Forms of Apoptosis, Necrosis and Autophagy. Cell Biol. Int. 2019, 43, 582-592. [CrossRef] [PubMed]

77. Nishida, K.; Yamaguchi, O.; Otsu, K. Crosstalk between Autophagy and Apoptosis in Heart Disease. Circ. Res. 2008, 103, 343-351. [CrossRef]

78. Jiang, P.; Mizushima, N. LC3- and p62-Based Biochemical Methods for the Analysis of Autophagy Progression in Mammalian Cells. Methods 2015, 75, 13-18. [CrossRef] [PubMed]

79. Sui, X.; Chen, R.; Wang, Z.; Huang, Z.; Kong, N.; Zhang, M.; Han, W.; Lou, F.; Yang, J.; Zhang, Q.; et al. Autophagy and Chemotherapy Resistance: A Promising Therapeutic Target for Cancer Treatment. Cell Death Dis. 2013, 4, e838. [CrossRef] [PubMed] 